\title{
The Determinants of Foreign Currency Hedging by U.K. Non-Financial Firms
}

\author{
Amrit Judge \\ Middlesex University, U.K.
}

For 366 large non-financial U.K. firms, this paper reports the factors that are important in determining their decision to hedge foreign currency exposure. The results provide strong evidence of a relationship between expected financial distress costs and the foreign currency hedging decision and more significantly the foreign currency only hedging decision. These findings seem stronger than those found in similar studies using U.S. data. The paper argues that this might be due to the fact that several U.S. studies include in their non-hedging sample other hedging firms, such as firms using non-derivative methods for currency hedging and interest rate only hedgers, which might bias the results against the a priori expectations. However, it might also be due to a country specific institutional factor, that is, U.K. firms face higher expected costs of financial distress due to differences in the bankruptcy codes in the two countries (JEL:F30, G32, G33).

Keywords: corporate hedging, foreign currency hedging, derivatives, financial distress, foreign currency debt, bankruptcy codes.

\section{Introduction}

Several studies have examined which theory of optimal hedging is consistent with the use of foreign currency derivatives (Wysocki [1995], Mian [1996], Géczy, Minton and Schrand [1997], Howton and Perfect [1998], Goldberg, Godwin, Kim and Tritschler [1998], Graham and Rogers [2000] and Allayannis and Ofek [2001]). Recently studies have

\footnotetext{
* I wish to thank Ephraim Clark, Paul Dunne, Brian Eales, Alex Rebmann, Nick Robinson, and Duncan Watson for their helpful comments and suggestions. I also thank seminar participants at Cass Business School, Cranfield University and Middlesex University Business School, and the participants at the MFS 2003 in Montreal, and the discussant Peter Theodossiou, the ISINI 2003 in Lille, the EFMA 2004 in Basel and the MMF 2004 in London.
}

(Multinational Finance Journal, 2006, vol. 10, no. 1/2, pp. 1-41)

(C) Multinational Finance Society, a nonprofit corporation. All rights reserved. DOI: $10.17578 / 10-1 / 2-1$ 
demonstrated that foreign currency debt is used in hedging firm's foreign currency exposure and in some instances can act as a substitute for foreign currency derivatives (Géczy et al. [1997], Allayannis and Ofek [2001], Keloharju and Niskanen [2001], Kedia and Mozumdar, [2003] Elliot, Huffman and Makar [2003]). However, none of the aforementioned foreign currency derivative studies incorporate foreign currency debt use into their definition of foreign currency hedging. ${ }^{1}$

It follows from this that the sample of non-users of currency derivatives in these studies might include firms that use foreign currency debt for hedging. If this is the case, a mis-classification of foreign currency hedging firms occurs, which might impair the ability to detect differences between foreign currency hedgers and non-foreign currency hedgers. This paper avoids this by widening the definition of foreign currency hedging to include firms that use foreign currency debt for hedging. ${ }^{2}$

A second potential problem in the composition of the non-foreign currency hedging sample of several previous foreign currency hedging studies is that the non-hedging sample includes non-foreign currency hedging firms that might be hedging interest rate and/or commodity price exposure (Wysocki [1995], Mian [1996], Géczy et al. [1997], Howton and Perfect [1998], Goldberg et al. [1998], Graham and Rogers [2000], Allayannis and Ofek [2001], and Hagelin [2003]). The inclusion of these "other" hedging firms in the non-hedging sample might make it more difficult to identify differences in financial and operating characteristics between foreign currency hedging and non-foreign currency hedging groups. ${ }^{3}$ Given that the majority of these "other" hedgers are interest rate hedgers, this might explain why previous empirical studies have not been able to detect a relationship between foreign currency hedging and variables such as leverage and interest cover which also proxy for the expected costs of financial distress. This

1. Géczy, Minton and Scrand (1997) use foreign currency debt as an exogenous variable in their model of foreign currency derivatives use and Allayanis and Ofek (2001) investigate separately the use of foreign currency derivatives and the use of foreign currency debt.

2. Graham and Rogers (2002) suggest that there could be a negative relation between debt and foreign currency derivatives use if foreign debt substitutes for currency derivatives hedging. They point out that if foreign debt is an adequate substitute for derivatives then it adversely affects the ability of their tests to detect a positive relation between hedging and debt.

3. Allayannis and Weston (2001) make a similar point and show the existence of a bias in their tests. 
study controls for this by excluding these "other" hedging firms from the non-foreign currency hedging sample. The tests show that the removal of these firms results in a stronger relationship between several exogenous variables and the foreign currency hedging decision.

The third contribution of this paper is the recognition that the sample of firms that hedge both foreign currency and interest rate exposure could be exerting undue influence on the relationship between foreign currency hedging and factors that are potentially more important for interest rate hedgers, such as the level of debt and debt servicing, which are used as proxies for the expected costs of financial distress. In order to control for this the study estimates specifications of the empirical model for a sample of foreign currency only hedgers. The empirical tests show that several proxies for financial distress are significantly related to the likelihood of foreign currency only hedging.

The paper proceeds as follows. Section II describes theories of optimal hedging, develops hypothesis and summarizes the paper's contribution to the existing literature on the determinants of foreign currency hedging. Section III describes the sample. Section IV presents tests on the determinants of foreign currency hedging and section $\mathrm{V}$ concludes.

\section{Corporate Hedging Theories and Evidence}

\section{Empirical Implications of Corporate Hedging Theories}

The foundation of our understanding of corporate financial policy is the Modigliani and Miller (1958) proposition. They demonstrated that given the firm's investment policy, with no taxes and no contracting costs, the firm's choice of financial policy does not affect the current market value of the firm. Smith and Stulz (1985) develop a positive theory of hedging by value maximizing firms in which hedging is part of overall corporate financing policy. They suggest that an equivalent statement of the Modigliani and Miller proposition is that if hedging is to affect firm value, then it must do so through changes in tax liabilities, through changes in stakeholder contracting costs, or through interdependencies between the choice of financial policy and future real investment decisions. This implies that hedging can increase firm value by simultaneously reducing external claims to the cash flow stream flowing from the firm's assets. Such claims include taxes paid to government by 
the firm; bankruptcy costs (both direct and indirect) paid to accountants, lawyers and the firm's non-investor stakeholders; and/or agency costs to align managerial interests with the interests of capital suppliers. Each has the potential to provide an explanation for the corporate demand for hedging.

\section{A. Corporate Tax Structure}

Smith and Stulz (1985) and Graham and Smith (1999) show that in the presence of a convex corporate tax function the firm's expected tax liability can be reduced by hedging. The more convex the tax schedule the greater the incentive to hedge. The factors that cause convexity in the effective tax function are progressivity in the statutory tax code and tax preference items such as tax loss carry-forwards, investment tax credits and foreign tax credits.

The range of progressivity in the U.K. corporate tax structure is relatively small since tax rates are progressive between profit levels of $£ 0$ and $£ 1.5 \mathrm{~m}$ and constant beyond $£ 1.5 \mathrm{~m}$. The majority of listed firms have pre-tax profits beyond the progressive region which suggests they face a linear effective tax function. ${ }^{4}$ This implies that for U.K. firms this tax based motive for hedging is potentially rather weak. Therefore, this aspect of a firm's tax function is not measured. Many U.K. firms do, however, report the existence of tax loss carry forwards in the notes to their accounts. Following several previous studies this study employs a dummy variable equal to 1 if the firm has tax loss carry forwards. ${ }^{5}$ This data is obtained from a search of notes to the accounts contained in annual reports. ${ }^{6}$

\section{B. Costs of Financial Distress}

Firms with greater variability of cash flows are more likely to find

4. Mian (1996), Wysocki (1996), Gay and Nam (1998) and Brown (2001) make a similar point for U.S. firms.

5. Graham and Rogers (2002) suggest that tax loss variables are inappropriate for capturing "incentives that result from the shape of the tax function" (p. 818). Furthermore, this variable may proxy for firms that have recently suffered from or are currently experiencing financial distress.

6. The appendix provides a summary of all explanatory variables used in the analysis and a detailed description of the method of calculation. 
themselves in financial distress, ceteris paribus. Smith and Stulz (1985) argue that the transaction costs of financial distress can induce firms to hedge financial price risks since the probability of incurring the costs is reduced. Most studies use the leverage ratio as an indicator of the likelihood of financial distress to measure expected costs of distress. However, a high level of debt does not necessarily imply a higher probability of financial distress, what is important is the ability to service the debt and pay it off at maturity. In view of this the interest coverage ratio, a firm's credit rating and a dummy variable indicating whether a firm has net interest payable or receivable are the preferred proxies for a firm's probability of financial distress. The use of these financial distress indicators also helps to address the potential problem of endogeneity of a firm's capital structure and hedging decision. Notwithstanding this, in order to facilitate comparisons with previous studies this study also employs a gross and net leverage ratio, where the latter measures total debt net of cash.

It is important to note that a higher probability of financial distress implies higher expected costs of financial distress on the assumption that exogenous bankruptcy costs are constant across firms. However, this assumption fails to consider the possibility that exogenous bankruptcy costs might affect the firm's capital structure choice (Géczy et al. [1997]). This study attempts to control for this by assuming firms within specific industries have a common exposure to financial distress and therefore uses an industry-adjusted leverage ratio. The industry-adjusted leverage ratio is calculated by scaling a firm's leverage ratio by its industry average. Firms with leverage above (below) the average for their industry will have an industry adjusted leverage ratio greater (less) than 1 . Firms are classified into industries using Datastream industry categories.

\section{Under investment Costs}

Hedging can reduce Underinvestment costs (Myers [1977]). Bessembinder (1991) argues that since hedging reduces the probability of financial distress it effectively shifts individual future states from default to non-default outcomes. The number of future states in which shareholders are the residual claimants increases and consequently they are more willing to provide funds for investment. Furthermore, the hedging firm can effectively commit to meet obligations in states where it otherwise could not and so negotiate better contract terms in the form 
of lower borrowing costs. Therefore risk management effectively expands the firm's "debt capacity".

Froot, Scharfstein, and Stein (1993) present an analysis whereby variability in cash flow will result in either variability in the amount raised externally or variability in the amount of investment in a way that decreases firm value. This is because by decreasing planned investment the firm is foregoing positive net present value projects and also since it has insufficient internal funds the firm is forced to raise costly external finance. According to Froot et al. hedging helps ensure the firm has sufficient internal funds which enables the firm to avoid unnecessary fluctuations in either investment spending or external financing and so increases firm value.

In both the Bessembinder (1991) and Froot et al. (1993) analysis the costs of Under investment will be greater for those firms with more growth options. This study employs four proxies for growth options. These are research and development expenditure deflated by total sales, capital expenditure deflated by total sales, the price earnings ratio and the market-to-book value of equity.

\section{Foreign Currency Exposure}

Firms with greater variation in cash flows or accounting earnings resulting from exposure to exchange rate risk have greater potential benefits of foreign currency hedging. For example, the probability of encountering financial distress is directly related to the firm's cash flow volatility (Smith and Stulz [1985]). The degree to which a firm's cash flows are affected by exchange rate changes should depend on the nature of its activities, such as the level of export and import activity, its involvement in foreign operations, its competitors currencies, and the competitiveness of its input and output markets. Unfortunately, data on firms' competitors' currencies and the market structure of their markets is not publicly available, however, data on foreign sales and imports and exports exists. Cash flow models of exposure suggest that the exposure should be related to net foreign currency revenues (total revenues minus costs). However, firms only report foreign currency revenues and not costs and so we are forced to employ this unrefined proxy for foreign currency exposure. ${ }^{7}$ Therefore, in this study the level of the firm's cash

7. Allayannis and Ofek (2001) suggest that the foreign sales ratio is an accurate proxy of the percentage of net foreign revenues out of total net revenues, if foreign profit margins 
flow exposure to foreign exchange rate changes is proxied using the ratio of overseas sales to total sales and a dummy variable denoting the existence of import and export activity. This data is sourced from a firm's annual report.

\section{E. Other Motives}

An alternative way to mitigate the effects of Under investment is for the firm to reduce the level of debt in its capital structure (Myers [1977]). However, lowering the firm's debt leads to a fall in the interest tax shield and the net effect might be a reduction in firm value. Nance et al. (1993) argue that firms can maintain the tax benefits of debt and control the Under investment problem by issuing convertible debt as opposed to straight debt. Convertible debt includes an embedded option on the firm's assets which makes this liability more sensitive to firm value changes and thereby reduces the sensitivity of equity to firm value changes and therefore reduces the incentive to hedge. However, Géczy et al. (1997) predict a positive relation between hedging and convertible debt on the assumption that convertible debt reflects additional leverage, which constrains a firm's access to external financing. In this study the use of convertible debt is measured by the ratio of book value of convertible debt to total assets.

A firm could lower the likelihood of financial distress by possessing more liquid assets ensuring that funds will be available to pay debt claims. Also firms with higher levels of liquidity will have less need to access costly external financing to fund their investment program. This study defines liquidity as cash and current investments over current liabilities.

All empirical studies examine the relationship between firm size and hedging. There are, however, competing arguments for either a positive or negative relation between firm size and hedging activity. The negative relationship between firm size and direct bankruptcy costs suggests that small firms have a greater incentive to hedge. Small firms are also faced with greater information asymmetries and higher financing transaction costs which are likely to make external financing more expensive for smaller firms and therefore hedging more likely. Conversely, hedging activity exhibits significant information and transaction cost scale economies implying that larger firms are more 
likely to hedge. This study uses the natural $\log$ of total assets to proxy for firm size.

\section{Overview of Hedging Studies}

It is well understood that capital market imperfections create an environment in which cash flow volatility due to exposure to financial prices might adversely affect shareholder wealth. The theories of hedging that model how these imperfections provide an incentive to hedge do not identify the source of the financial exposure. In view of this most of the early studies on the determinants of hedging investigate the firm's decision to hedge any type of financial price exposure, that is, interest rate, foreign currency or commodity price exposure (Francis and Stephan [1993], Nance, Smith and Smithson [1993], Dolde [1995], Wysocki [1996], Berkman and Bradbury [1996] and Fok, Carroll and Chiou [1997]).

Recent studies have focused on the type of exposure hedged, such as foreign currency exposure, with a view to demonstrating that different factors may be important for each type of hedging. Four studies investigate the use of foreign currency hedging instruments (Wysocki [1995], Géczy et al. [1997], Allayannis and Ofek [2001] and Hagelin [2003]) and a further four examine separately the determinants of interest rate and foreign currency hedging (Mian [1996], Howton and Perfect [1998], Goldberg et al.[1998], and Graham and Rogers [2000]).

A feature of this study that distinguishes it from previous empirical tests of foreign currency hedging is how it defines foreign currency hedging. Most previous studies identify foreign currency hedgers as firms that use foreign currency derivatives and ignore firms adopting other foreign currency hedging methods (Wysocki [1995], Mian [1996], Goldberg et al. [1998], Howton and Perfect [1998], Graham and Rogers [2000] and Allayannis and Ofek [2001]).

Recently studies have demonstrated that foreign currency debt is used in hedging firm's foreign currency exposure (Allayannis and Ofek, [2001], Kedia and Mozumdar, [2003], Elliot et al., [2003]). Kedia and Mozumdar (2003) suggest that an implication of this result is that studies of foreign currency hedging "need to go beyond the firms' derivative positions and look at other financial and operational hedges to fully comprehend the firms' exposures and risk management activities" (p. 545). Guay and Kothari (2003) also stress the importance of considering a multifaceted approach to hedging in empirical studies 
of corporate risk management. They find that derivatives usage by many U.S. non-financial firms is too small relative to their risk exposures. They suggest that this result is potentially consistent with firms "using derivatives to 'fine tune' their overall risk-management program that likely includes other means of hedging" (p. 425). They go on to suggest that this implies that derivatives use is a noisy proxy for firms' risk management activities which might explain the mixed results reported in the literature such as those pertaining to financial distress and Under investment costs.

Some studies, however, do include foreign currency debt use, but this is as an exogenous variable in models explaining currency derivatives hedging (Géczy et al., [1997] and Hagelin [2003]). These studies report a positive coefficient for the foreign debt variable which is consistent with foreign debt acting as a complement to derivatives or creating a foreign currency exposure on average. This approach and that of excluding alternative risk management methods, such as choosing to finance in the currency of the firm's assets, fails to distinguish between foreign currency derivative use and foreign currency risk management. For example, two firms may manage their foreign currency exposure arising from foreign assets, one firm using a currency swap to create a liability in the required currency, and the other using foreign denominated debt to act as a natural hedge of foreign revenues. Therefore, by equating "foreign currency hedger" with "foreign currency derivative user," the former would be characterized as a "hedger" and the latter a "non-hedger". ${ }^{8}$ This approach would make it far more difficult to identify differences between foreign currency hedgers and foreign currency non-hedgers. The sample in this study contains many instances of firms using foreign currency debt in isolation or in combination with derivatives for hedging foreign currency exposure. For example:

Rugby PLC writes, "The Group seeks to mitigate the impact of extreme movements in foreign exchange rates on shareholders' funds by holding foreign currency borrowings to hedge certain of its assets overseas. As a consequence the Group incurs interest costs in the same currencies as those in which it generates operating profit, thereby also reducing the impact of foreign exchange movements on reported earnings." (p. 19) British Gas writes, “... exposure to foreign exchange risk is minimized

8. Tufano (1996) makes a similar point when investigating risk management activities in the U.S. gold mining industry. 
by the use of financial instruments and by raising overseas finance to hedge against overseas assets." (p. 21)

Adwest writes, "The Group hedges the effect of exchange rate movements on the translation of foreign currency net assets by using foreign currency borrowings and foreign currency swap contracts." (p. 22)

Smith and Nephew writes, "The group protects shareholders funds by matching, where practicable, foreign currency assets, including acquisition goodwill, with currency liabilities. These currency liabilities take the form of either borrowings or currency swaps." (p. 27)

BOC Group writes, "Usually foreign currency investments are hedged by borrowings in the same currency, either by means of direct borrowings or the use of foreign currency swaps." (p. 37)

These examples demonstrate that foreign debt can substitute for or act as a complement to currency derivatives for hedging. Therefore, in this study foreign currency hedging firms are defined as those that mention in their annual report that they use foreign debt or currency derivatives or any other method for foreign currency hedging.

A second and hitherto unrecognized problem for the aforementioned foreign currency hedging studies is the inclusion of firms hedging other exposures in the sample of non-foreign currency hedgers. ${ }^{9}$ The dependent variable in these studies is set equal to 1 if firms use foreign currency derivatives to hedge foreign exchange exposure and 0 if they do not use currency derivatives. Therefore, the sample of non-foreign currency derivative users might include firms that use interest rate or commodity price derivatives but not currency derivatives. Table 1 provides details of the composition of the non-foreign currency hedging samples of eight previous studies investigating foreign currency hedging. All of these studies include in their sample of non-foreign currency hedgers firms hedging other exposures.

In some instances other derivative users can make up around a quarter of non-foreign currency derivative using firms (i.e., non-foreign currency hedging firms). For example, table 1 shows that in Géczy et al. (1997) 30.1 percent of the non-user sample are other derivative users, in Goldberg et al. (1998) the figure is 28 percent and in Graham and Rogers (2000) they make up 24 percent. Most surveys of derivative use tend to show that foreign currency and interest rate derivatives are the

9. Allayannis and Weston (2001) also mention this problem but this is in the context of measuring the impact of foreign currency derivatives use on firm value. 
most popular categories of derivatives used whereas the use of commodity price derivatives is less frequent. This is usually because only a small proportion of the sample surveyed face commodity price exposure..$^{10}$ This suggests that the majority of "other" hedgers in the non-foreign currency hedging samples of the foreign currency studies cited in table 1 are likely to be interest rate hedgers.

It follows that the existence of interest rate hedgers in the non-foreign currency hedging sample might impair the ability of studies to find statistically significant links between foreign currency hedging and factors that are relatively more important to interest rate hedgers, such as variables indicating debt levels and debt servicing ability. Furthermore, since these variables usually act as proxies for the expected costs of financial distress this might explain why in probit/logit tests no previous foreign currency studies, such as those cited in table 1 , find evidence in support of this hypothesis. ${ }^{11}$

None of these studies recognize the potential bias created by the existence of "other" hedging firms in the non-foreign currency hedging sample. This paper demonstrates empirically the effect of controlling for this bias, namely that we see an improvement in the results and in particular those pertaining to financial distress. The assertion of this paper is that if previous studies had controlled for interest rate hedgers in the non-foreign currency hedging sample, then they might also have found evidence supporting the financial distress hypothesis. This is

10. Phillips (1995) reports that of those firms with less than $\$ 250$ million in sales, $86 \%$ face interest rate risk, $73 \%$ face foreign exchange risk, and $30 \%$ face commodity price risk. Among large firms, he reports that $97 \%$ face interest rate risk, $91 \%$ face foreign exchange rate risk and $63 \%$ face commodity price risk.

11. For example, Géczy et al. (1997) use the long-term debt ratio, an industry adjusted debt ratio and $\mathrm{S} \& \mathrm{P}$ credit ratings and find no evidence in support of the financial distress cost hypothesis. Furthermore, they present mixed evidence for proxies measuring underinvestment costs, which can be used to measure expected distress costs (Graham and Rogers [2002]). Goldberg, Godwin, Kim \& Tritschler (1998) find that leverage is not significantly related to the foreign currency hedging decision in both univariate and multivariate probit tests. Graham and Rogers (2000) find using a probit model no significant relation between foreign currency hedging and measures for financial distress costs, such as debt ratio, debt ratio times market-to-book ratio, firm profitability, tax losses and credit ratings. Allayannis and Ofek (2001) use debt ratio, return on assets, Altman's z-score and liquidity in a probit model and find that the debt ratio is significantly negatively related to foreign currency hedging (opposite to that predicted by theory) and the other measures are not significantly related to foreign currency hedging. In both univariate and multivariate tests Hagelin (2003) finds no support for the financial distress hypothesis. He says this lack of evidence "is in accordance with earlier studies on use of currency derivatives." (p. 65) 


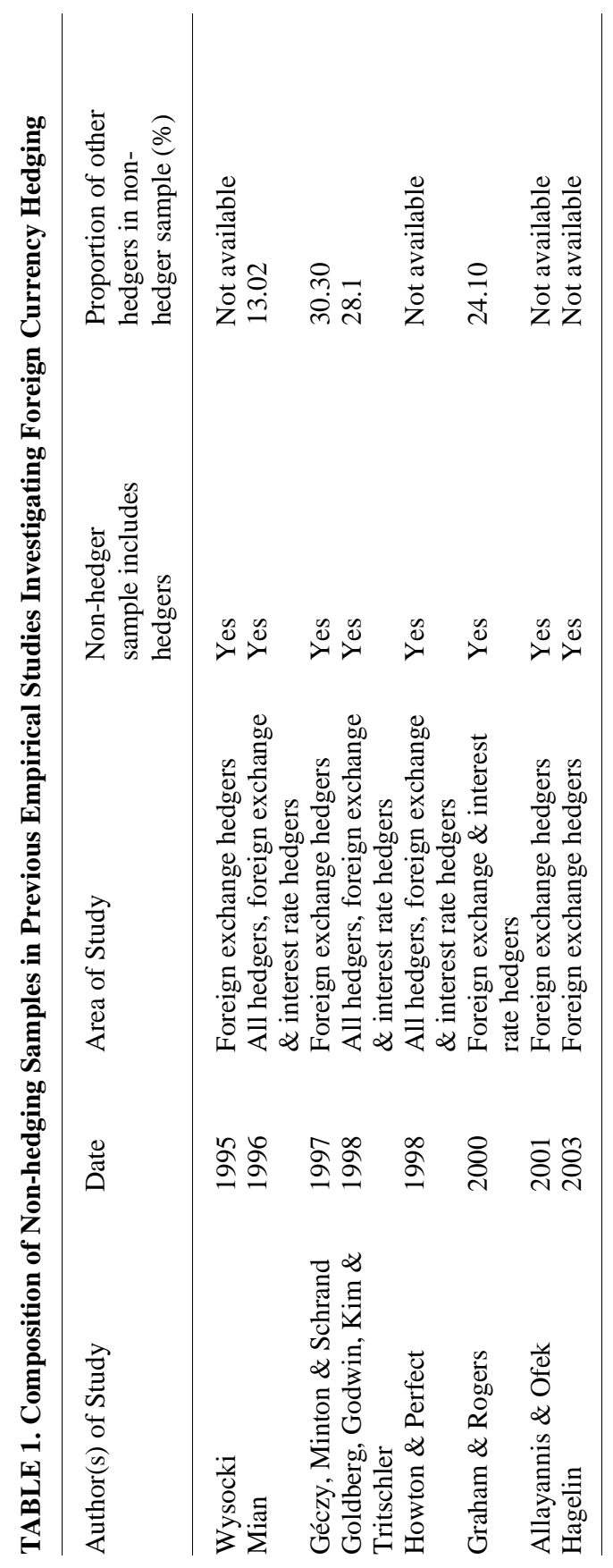


particularly the case given the large proportion of other hedgers in some instances.

Finally the paper controls for the possibility that a sample of foreign currency hedgers that also includes interest rate and commodity price hedgers engenders bias. This is important because, for example, firms that hedge both foreign currency and interest rate exposure might drive the relationship between foreign currency hedging and factors that are potentially more relevant to interest rate hedgers such as leverage and interest cover. By removing interest rate hedgers from the foreign currency hedging sample, the multivariate tests avoid any bias which might act in favor of finding a positive link between foreign currency hedging and the aforementioned variables, which are usually used as proxies for the expected costs of financial distress. Employing a sample of foreign currency only hedgers is the only unambiguous method for determining which factors are important in the foreign currency hedging decision. ${ }^{12}$ In this way the tests in this paper investigate the decision to hedge foreign currency exposure and not the decision to hedge both foreign currency and interest rate exposure.

\section{Sample Description and Sources of Data on Foreign Currency Hedging}

Sample Construction and Identification of Ex Ante Exchange Rate Exposure

This study analyses the foreign currency hedging practices of non-financial firms in the top 500 of U.K. firms ranked by market value as of year-end 1995. The sample consists of 441 non-financial firms. This study sources information on foreign currency hedging practices from annual reports. The annual reports of 412 firms out of the initial sample of 441 firms were obtained.

Following Géczy et al. (1997) and Graham and Rogers (2002) this study excludes firms that do not face foreign currency exposure.

12. Géczy et al. (1997) and Graham and Rogers (2000) include a dummy variable indicating the use of other types of derivatives as an independent variable in their specifications. They find that the likelihood of using currency derivatives is positively affected by the use of other types of derivatives, such as interest rate derivatives. They suggest that this is consistent with the notion that there are scale economies to operating a risk management program with derivatives. 
Therefore in our sample a non-hedging firm has decided not to hedge its exchange rate exposure which is different to that of a firm not hedging because it has no exposure to exchange rate risk. I use the following as indicators of foreign currency exposure: ${ }^{13}$

1. Reporting foreign sales in the notes to the accounts.

2. Disclosure of foreign taxes in the notes to the accounts.

3. Qualitative discussion of the existence of import or export activity or foreign operations in the annual report. ${ }^{14}$

The final sample comprises 366 firms that have at least one of the above sources of foreign currency exposure. None of the 46 firms eliminated through this process are foreign currency hedgers or foreign currency derivative users.

\section{Annual Report Disclosures of Foreign Currency Hedging Practices}

Panel A of table 2 shows that 79.2 percent of firms disclosed they hedged foreign currency exposure, 0.6 percent stated that they did not hedge foreign currency exposure and 20.2 percent had no discussion of foreign currency hedging. Non-hedgers and firms with no discussion of hedging are combined to form one group of "non-hedgers of foreign currency exposure". Foreign exchange hedging firms are also hedging other exposures such as interest rate and commodity price risks. Panel $\mathrm{B}$ of table 2 shows that 44.1 percent of foreign exchange hedgers only hedge this exposure whilst 55.9 percent hedge at least one other type of exposure. Amongst this latter group the most frequent combination is that of foreign exchange and interest rate hedging.

Panel $\mathrm{C}$ of table 2 shows that the sample of foreign exchange non-hedgers consists of both non-hedging firms and firms hedging other exposures. The latter make up 15.8 percent of foreign exchange

13. Unlike Géczy et al. (1997) I do not use foreign currency debt as an indicator of foreign currency exposure. This is because for 84 percent of foreign debt users, qualitative disclosures in annual reports suggest that foreign debt is used for hedging purposes. Furthermore, in only 8 percent of cases did qualitative disclosures indicate that firms' use of foreign debt increased their foreign currency exposure. All of these firms were identified as having foreign currency exposure using this study's preferred indicators of exposure. For the remaining cases it was not possible to determine the potential impact of foreign currency borrowings on the firm's foreign currency risk profile.

14. Firms with purely domestic operations (i.e. no foreign sales or imports) may be exposed to exchange rates through domestic or foreign competitors who import or export. Due to non-availability of public data this aspect of a firm's foreign currency exposure profile is not accounted for. 
non-hedgers of which nearly all are interest rate only hedgers. It was suggested above that the inclusion of these hedgers in the non-foreign currency hedging sample might bias the empirical results against the a priori expectations. However, this proportion of other hedgers is smaller than that observed in Géczy et al. (1997), Goldberg et al. (1998) and Graham and Rogers (2000), and therefore the bias might not be as strong as that experienced in these studies.

Panel D shows that 58.7 percent of firms disclose the use foreign currency derivatives for hedging. This is higher than figures between 41 and 45 percent reported in three U.S. studies (Géczy et al. [1997], Howton and Perfect [1998], Allayannis and Ofek [2001]) but slightly lower than Hagelin (2003) who reported that 60 percent of Swedish firms use currency derivatives. The descriptive statistics for the independent variables used in the multivariate analysis are presented in table 3 .

\section{Empirical Analysis of Foreign Currency Hedging}

\section{Multivariate tests and results}

Univariate tests tend to be weak since they do not allow for interactions among the independent variables. Therefore this section presents the results of multivariate tests which examine the effects of the independent variables on the firm's foreign currency hedging decision. ${ }^{15}$ The regressions employ a binary measure of foreign currency hedging. Firms that hedge foreign currency exposure are assigned a value of one for the binary variable, and all other firms are assigned a value of zero. Given the dichotomous nature of the dependent variable, I estimate a logit regression to investigate the factors that affect the foreign currency hedging decision. In these regressions, the binary foreign currency hedging variable is regressed on variables that measure tax function convexity, expected costs of financial distress, firm growth, foreign currency exposure, transaction cost economies of scales and control variables for hedging substitutes. The coefficients for the variables measuring firm growth and convertible debt usage are not statistically

15. The results of comparisons between foreign currency hedgers and non-foreign currency hedgers using $t$-tests and Wilcoxon rank sum tests are available upon request. 


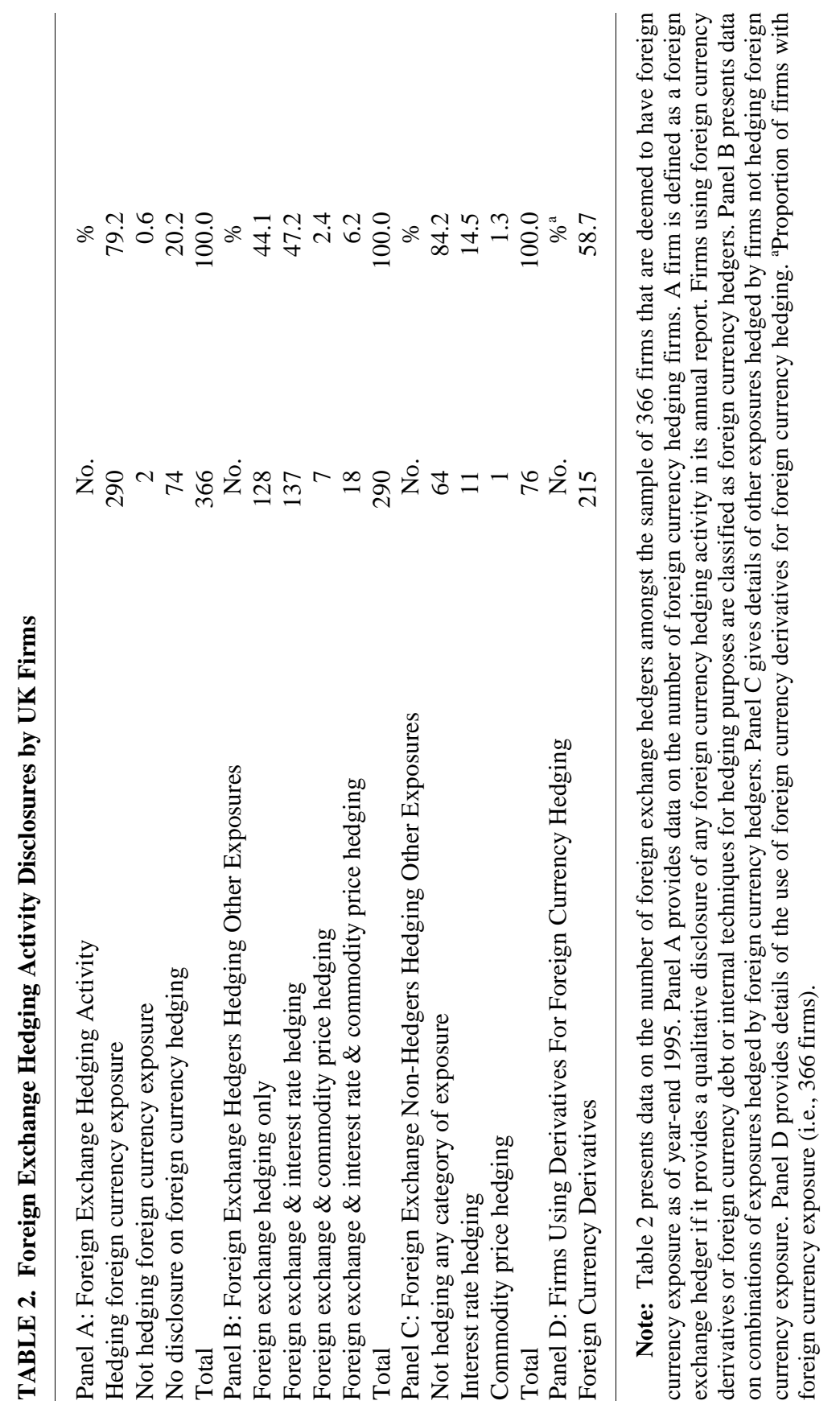




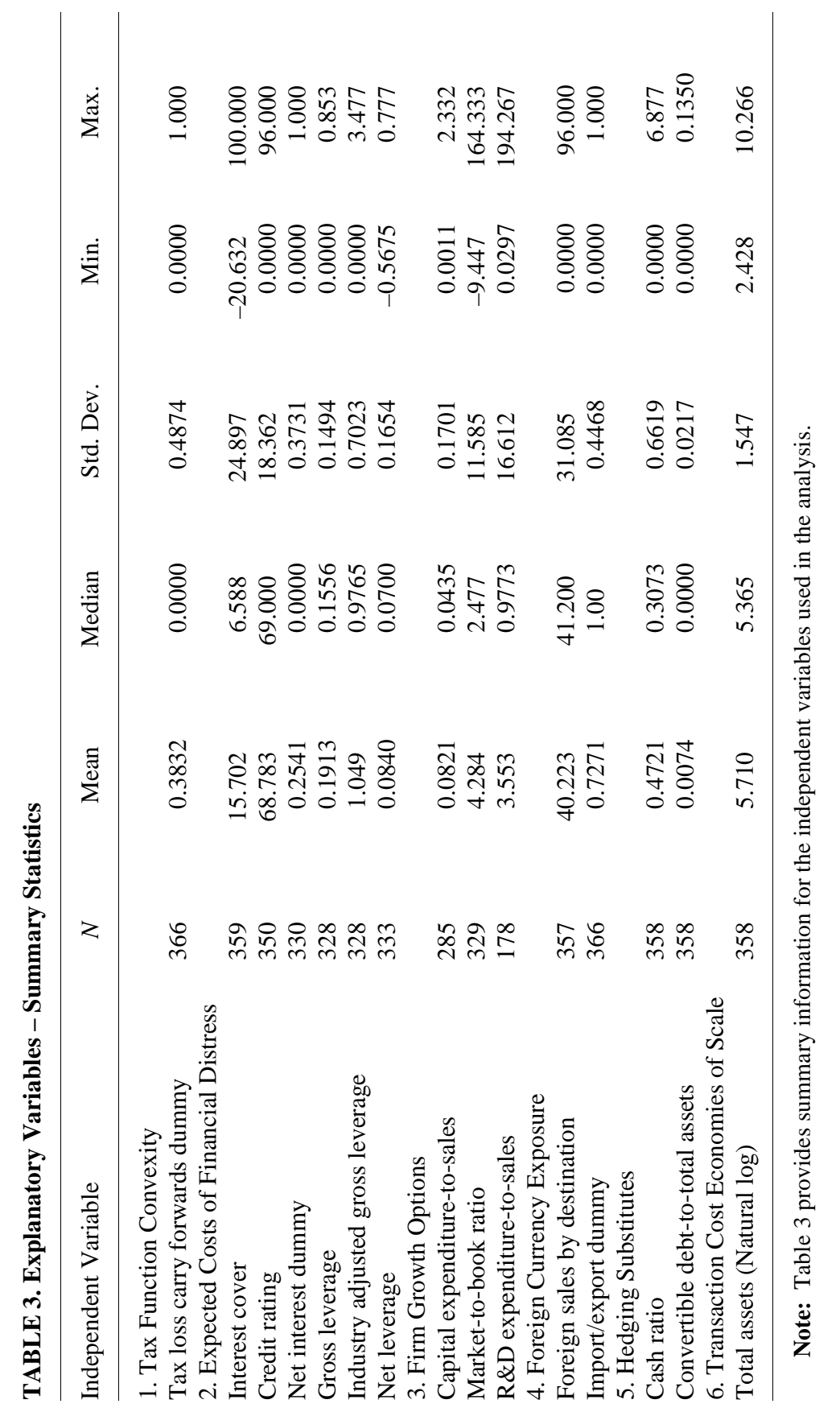


significant in these regressions and therefore are ignored in subsequent multivariate regressions. The conclusions are not affected by excluding these variables.

The results from fitting the logit model are presented in table 4 models 1 through to 6 . The table reports both the estimated coefficient and elasticity for each variable. The elasticity measures the importance of a variable in the model, where more important variables have larger elasticity values. The elasticities show that firm size is ranked as the most important explanatory variable in the model. The second most important variable is the foreign currency transactions dummy, followed by the proxies for the expected costs of financial distress, the tax loss dummy and the cash ratio. These results provide support for the information and transaction cost economies of scale hypothesis, the foreign currency exposure hypothesis, the financial distress cost hypothesis, the substitutes for hedging hypothesis and the costs of external finance hypothesis.

To my knowledge this is the only study to find using logit or probit regression methodology a significant positive relationship between foreign currency hedging and a proxy for expected financial distress costs. In particular, the results show that the decision to hedge foreign currency exposure is significantly negatively related to the level of interest cover, a firm's credit rating and if it is in receipt of net interest. These findings are consistent with Mayers and Smith (1982), Smith and Stulz (1985), Mayers and Smith (1987), Bessembinder (1991) and Froot et al. (1993) who argue that hedging facilitates a reduction in financial contracting costs. However, the three measures of leverage employed in this study, gross leverage, industry adjusted gross leverage and net leverage, are not significantly related to the foreign currency hedging decision.

The results show that financing constraints measured by firm liquidity provide incentives for hedging. These results are generally stronger than those observed in previous studies (Mian [1996], Géczy et al. [1997], Howton and Perfect [1998], Graham and Rogers [2000] Allayannis and Ofek [2001] and Hagelin [2003]). A higher cash ratio implies a significantly lower probability of foreign currency hedging. This result is consistent with the Froot et al. prediction that hedging activity is beneficial because it secures the availability of internal funds. It also supports the Nance et al. prediction that the existence of negative debt (i.e., cash) reduces a firm's relative need to hedge because the agency costs of debt and the expected costs of financial distress are 
lower.

Consistent with previous studies the empirical tests provide evidence that a firm's foreign currency exposure factors are significantly and positively related to hedging. Finally, the positive firm size effect may indicate that there is a significant fixed cost component to implementing a foreign currency hedging program, and small firms are less likely to achieve sufficient benefits to offset this cost. This finding is inconsistent with the notion that small firms face substantial informational asymmetry costs and therefore are more likely to hedge.

Excluding Other Hedgers from the Non-Foreign Currency Hedging Group

The tests in the previous section investigated the determinants of foreign currency hedging using samples of foreign currency hedgers versus non-hedgers of foreign currency exposure. Table 2 shows that the group of non-foreign currency hedgers includes firms hedging interest rate and/or commodity price exposure. This paper argues that the inclusion of these firms, referred to as "other" hedging firms, in the non-hedging sample might potentially bias the results against finding particular hypothesized relationships. Since the majority of other hedgers are interest rate hedgers this might make it difficult to detect a relationship between foreign currency hedging and those factors of greater relevance to interest rate hedgers such as levels of debt and the ability to service debt. The results for models 1 to 6 in table 4 bear this out to some extent, since although interest cover, credit rating and net interest receivable are significantly related to the foreign currency hedging decision leverage, in its various forms, is not. However, an alternative explanation for the distress cost results might be that variables like interest cover, credit rating and net interest are better proxies for the expected costs of financial distress than leverage. Since it could be argued that a high level of debt does not necessarily imply a higher probability of financial distress, but what in fact matters is the ability to service debt and redeem it at maturity. ${ }^{16}$ Despite this many previous foreign currency hedging studies use leverage to measure expected costs of financial distress (Géczy et al. [1997], Goldberg et al. [1998], Howton and Perfect [1998], Graham and Rogers [2000], Allayannis and 


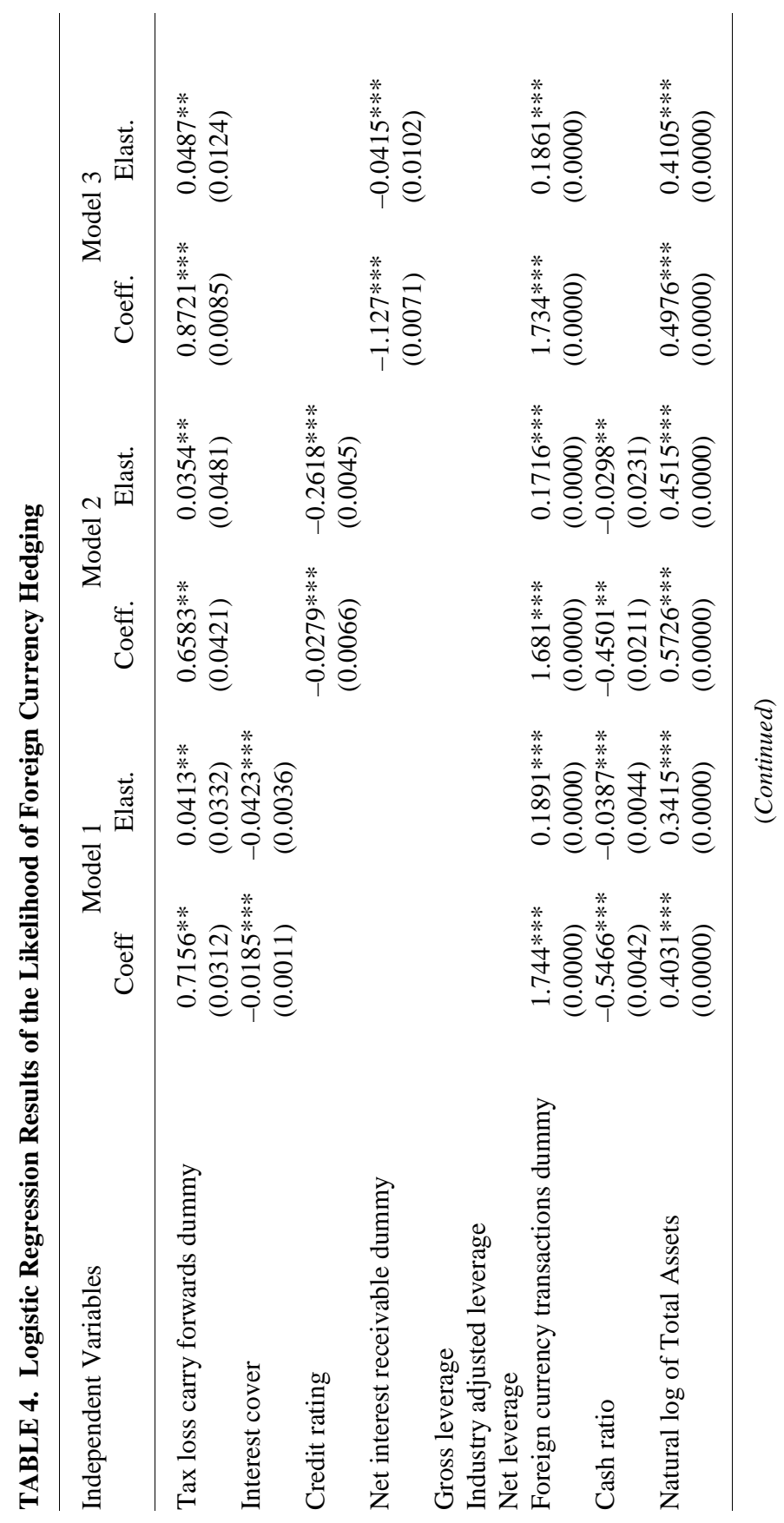




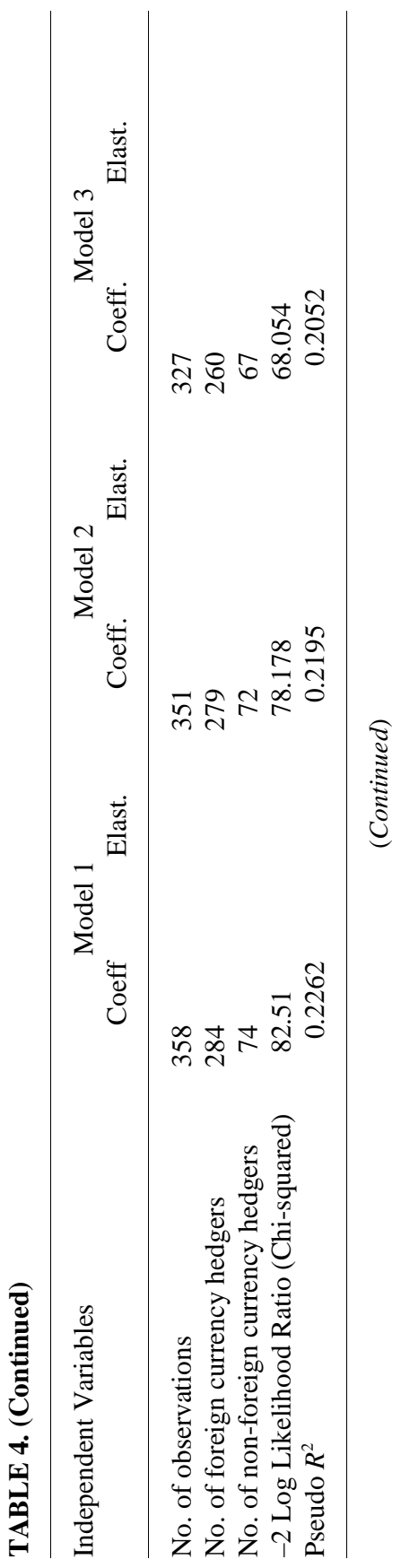




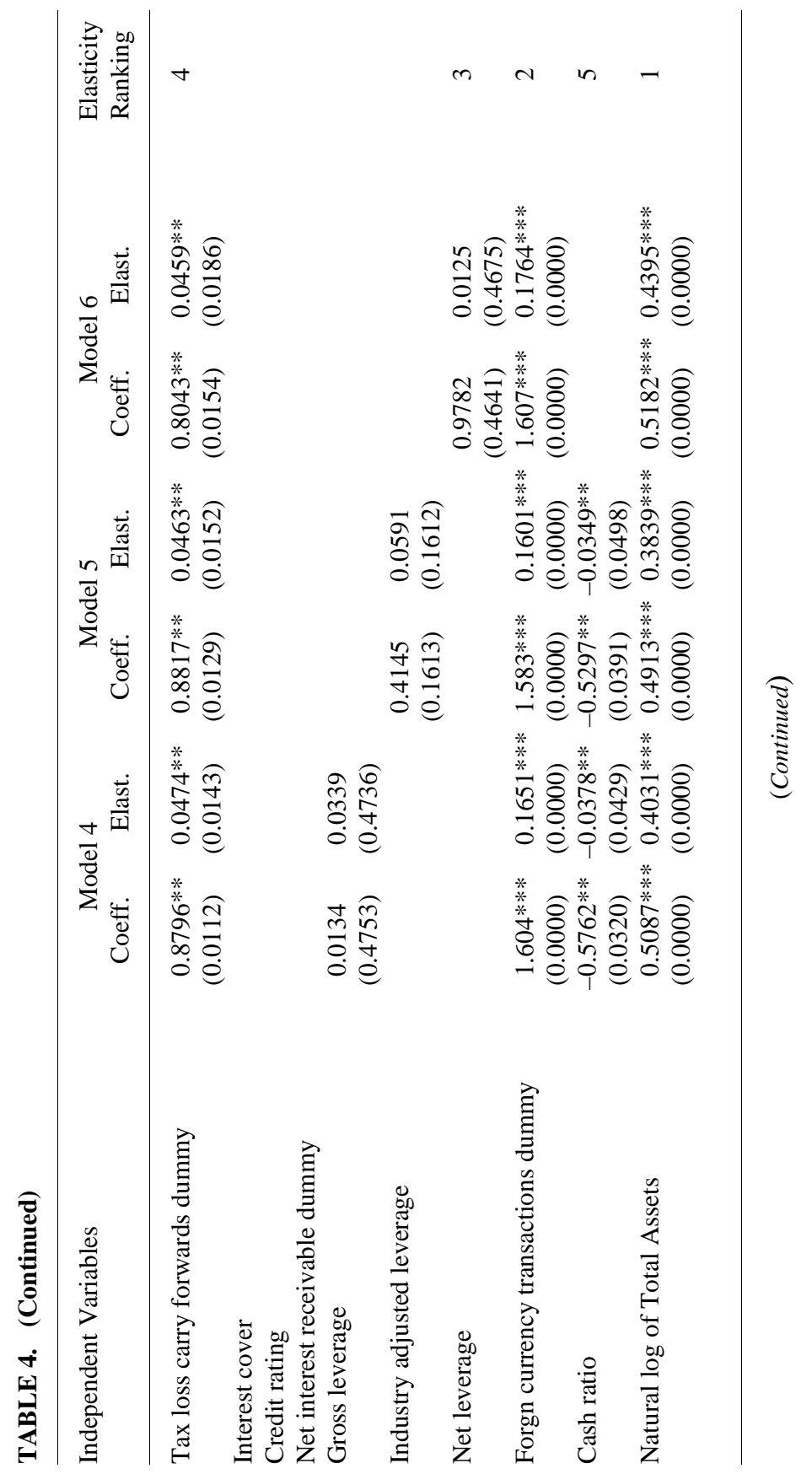




\section{Foreign Currency Hedging}

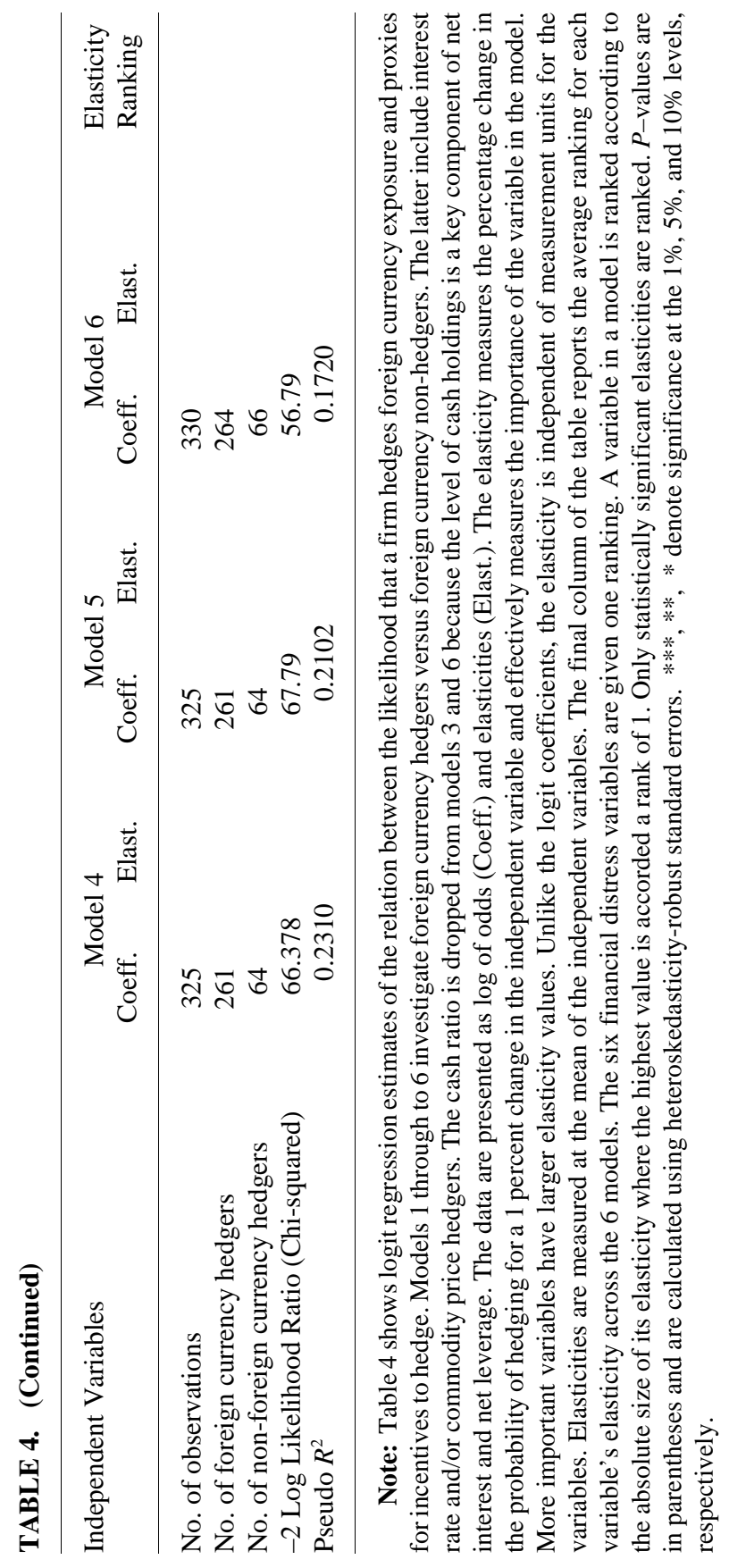




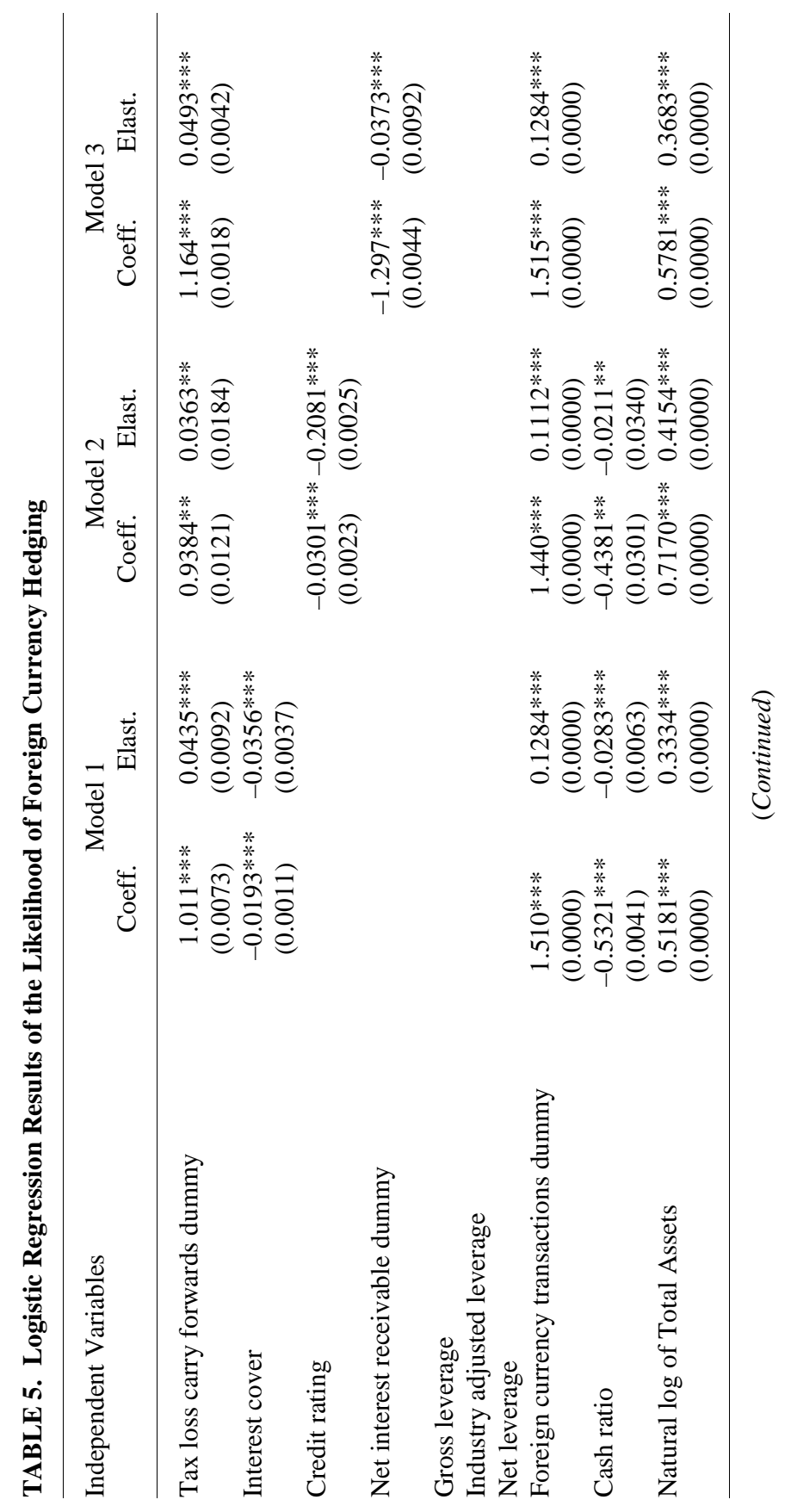




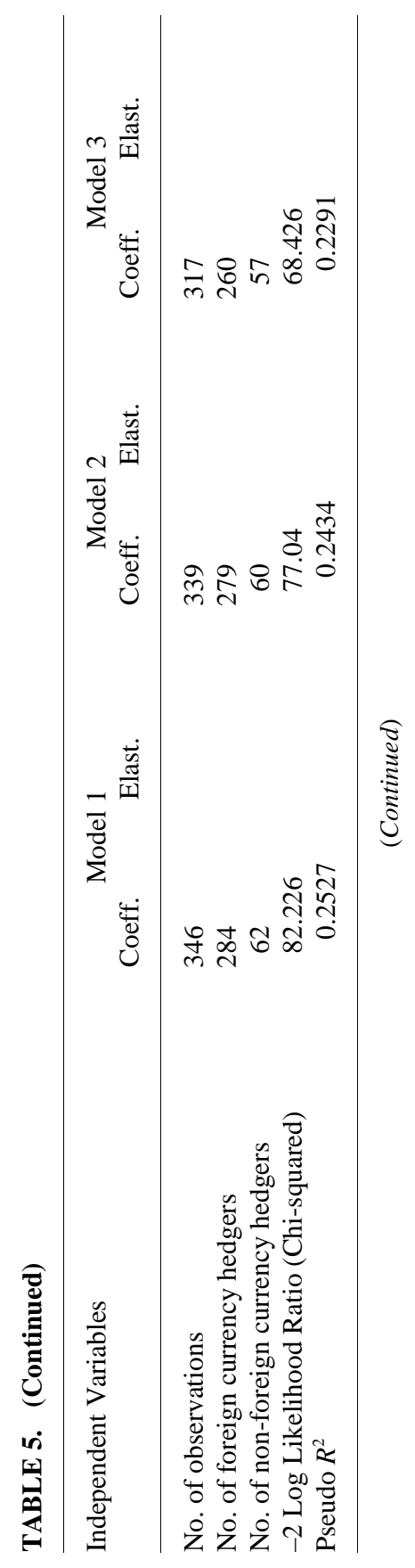




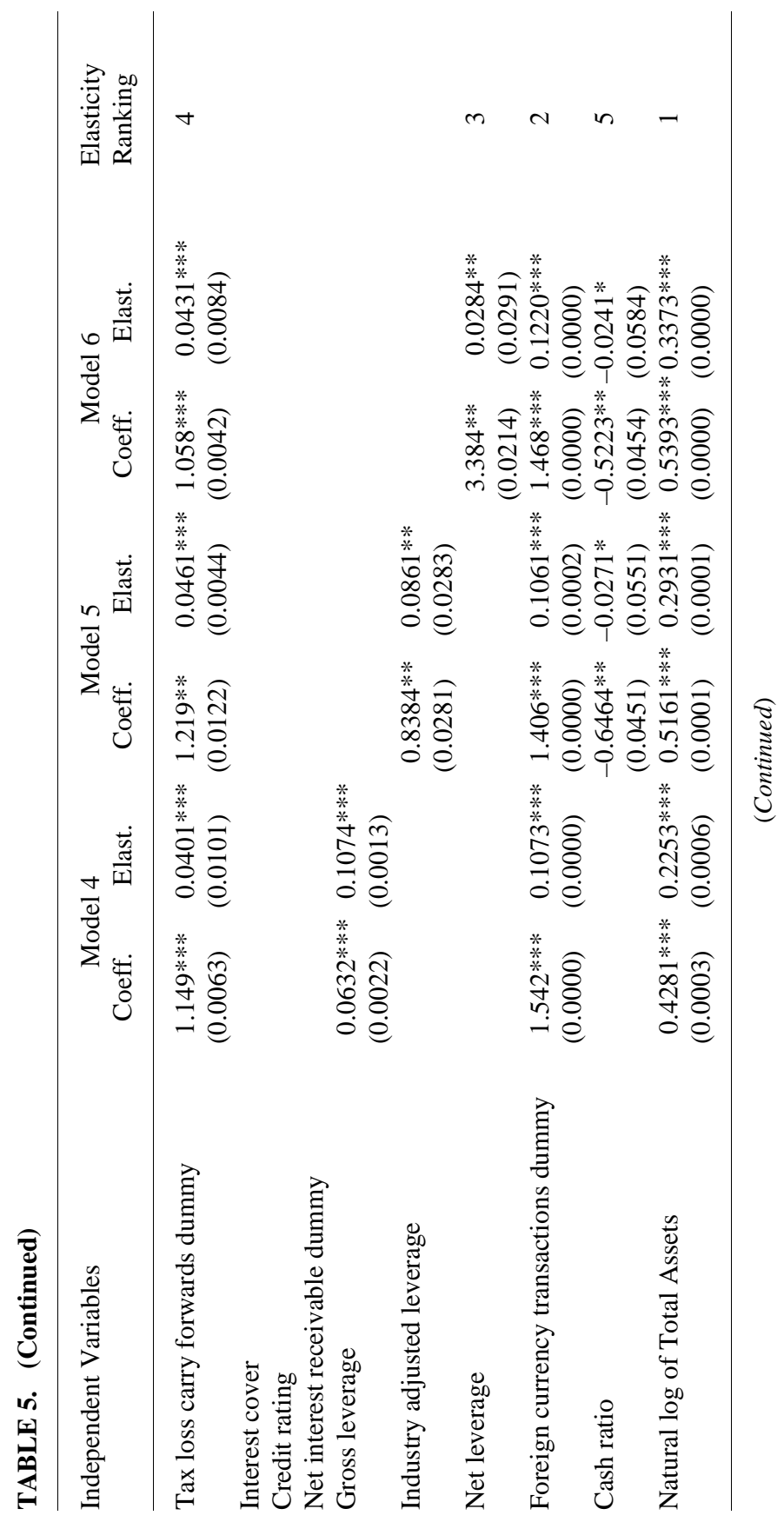




\section{Foreign Currency Hedging}

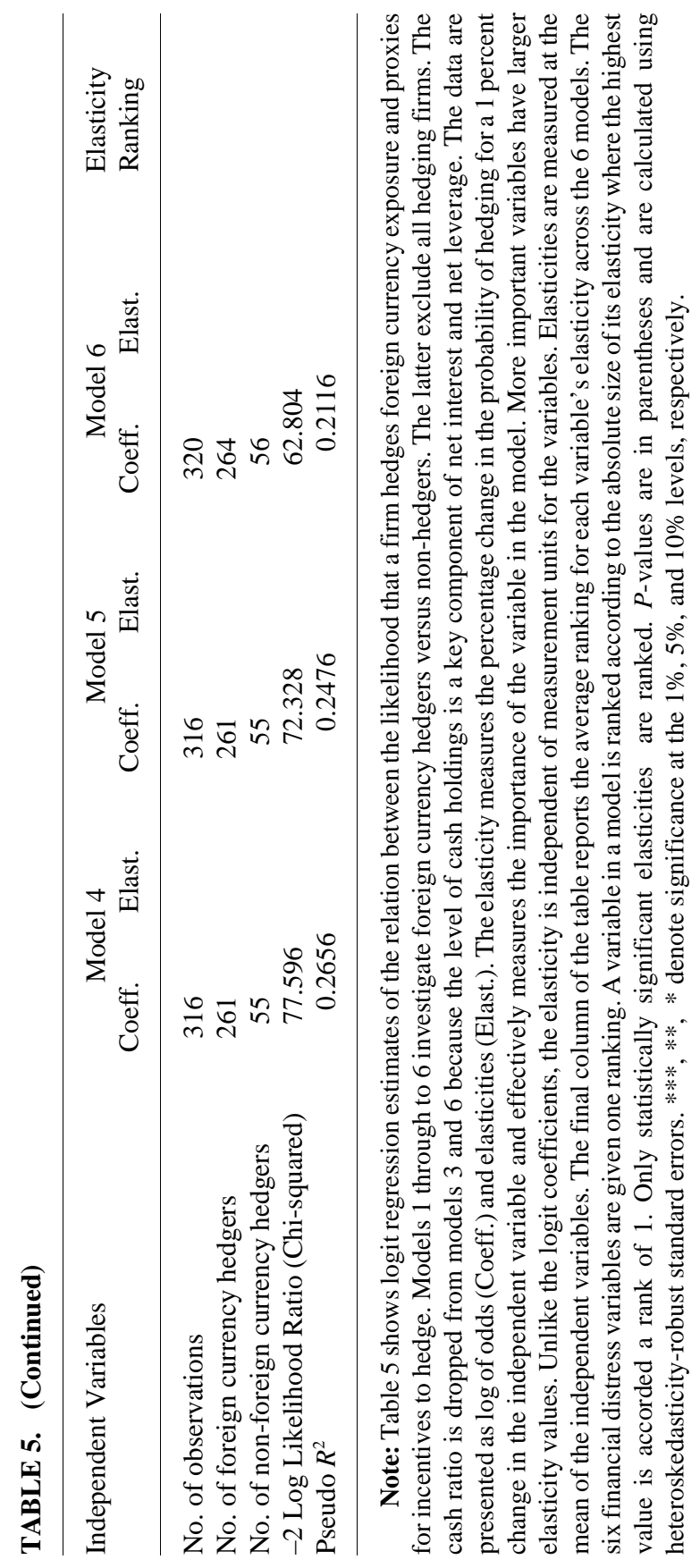


Ofek [2001] and Hagelin [2003]). Like this study none of the previous studies found a significant positive relationship between foreign currency hedging and leverage. Therefore to investigate whether the insignificant leverage results in this study might be due to the inclusion of other hedgers, models in table 4 are refitted excluding other hedging firms from the non-foreign currency hedging sample. These results, presented in table 5, show that all three measures of leverage are now significantly positively related to foreign currency hedging and that the coefficients for the other distress cost proxies have increased. Overall, all six proxies for financial distress are statistically significant after the exclusion of "other" hedging firms, whereas only three were prior to the removal of these firms.

These findings demonstrate that the inclusion of other hedgers in the non-foreign currency hedging sample of this study adversely affects the ability to detect a relationship between foreign currency hedging and some proxies for the expected costs of financial distress. This is the case despite the fact that the non-foreign currency hedging sample contains only 15.8 percent of other hedgers. As mentioned previously a common feature of eight previous studies cited in table 1 is the inclusion of other hedging firms in their non-foreign currency hedging sample. In some instances (Géczy et al. [1997], Goldberg et al. [1998] and Graham and Rogers [2000]) samples of non-foreign currency derivative users contain around a quarter of firms that are using other derivatives. Since this proportion is greater than that for the sample employed in this study, it is conceivable that the bias in the aforementioned studies could be greater. Their results would seem to bear this out since none reported a link between expected costs of financial distress and the decision to hedge foreign currency exposure. Furthermore, none of the other foreign currency hedging studies found a significant relationship either and only two studies report a significant relationship between hedging and liquidity (Géczy et al. [1997] and Howton and Perfect [1998]). The results presented here provide evidence in support of the notion that the inclusion of "other" hedgers (in particular interest rate hedgers) in non-foreign currency hedging samples might explain why previous studies have failed to detect a relationship between foreign currency hedging and measures for expected costs of financial distress.

\section{Multivariate Tests for Foreign Currency Only Hedgers}

The results in the previous sections indicate that tax loss carry forwards, 
proxies for financial distress costs, measures of foreign currency exposure, liquidity and firm size significantly affect the likelihood of foreign currency hedging. It was also noted that these relationships prevailed despite the existence of "other" hedgers in the non-foreign currency hedging sample. Given that most of these "other" hedgers are interest rate hedgers it is somewhat surprising that the results show a strong relationship between foreign currency hedging and variables employed to proxy for the expected costs of financial distress, such as interest cover and credit rating. This evidence would seem to suggest that financial distress costs are an important factor in determining the decision to hedge foreign currency exposure. However, the validity of the strength of this link can be called into question because of the structure of the foreign currency hedging sample.

Closer inspection of the foreign currency hedging sample reveals a few interesting characteristics. Table 2 shows that 44.1 percent of foreign currency hedgers are foreign currency only hedgers and 53.4 percent of foreign currency hedgers also hedge interest rate exposure. It could be argued that since over half the sample of foreign currency hedgers are also interest rate hedgers it is quite possible that this group of firms is driving the results with respect to those variables that are potentially of greater relevance to interest rate hedging firms such as the level of debt and the firm's ability to service its debt.

The empirical tests in this section examine this by investigating the determinants of foreign currency only hedging (i.e., firms that only hedge foreign currency exposure). The results of this analysis are presented in table 6 . Like table 5 the models in table 6 exclude "other" hedging firms from the non-foreign currency hedging sample. The results show that all of the expected distress cost proxies as well as the cash ratio are significantly related in the hypothesized direction to the decision to only hedge foreign currency exposure. An important implication of these results is that they show that the observed link between foreign currency hedging and financial distress is not driven by the inclusion of foreign currency hedging firms that also hedge interest rate exposure. This demonstrates empirically, to my knowledge for the first time, an unequivocal link between the foreign currency hedging decision and the expected costs of financial distress. ${ }^{17}$

17. In unreported analysis I ran the regressions in table 6 including "other" hedgers in the non-hedging sample. The results showed that the leverage variables were no longer significant although the other distress proxies were. These results are qualitatively similar to those reported in table 4 . 


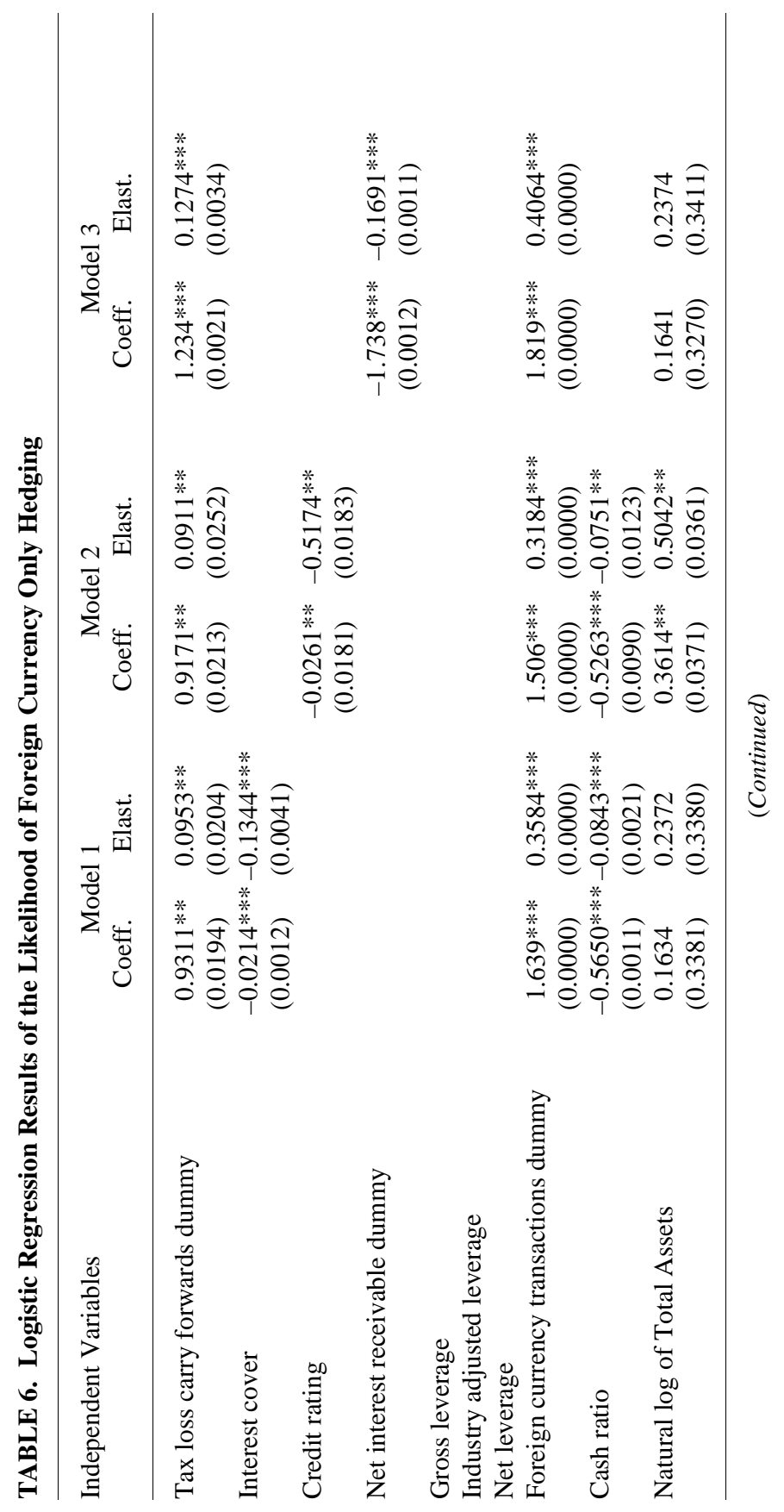


Foreign Currency Hedging

31

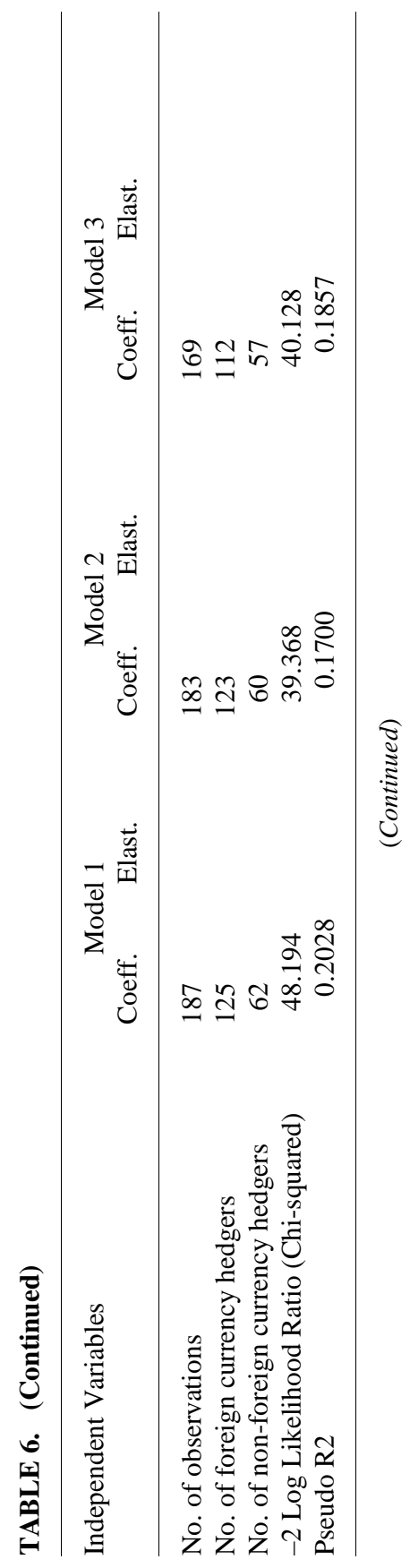




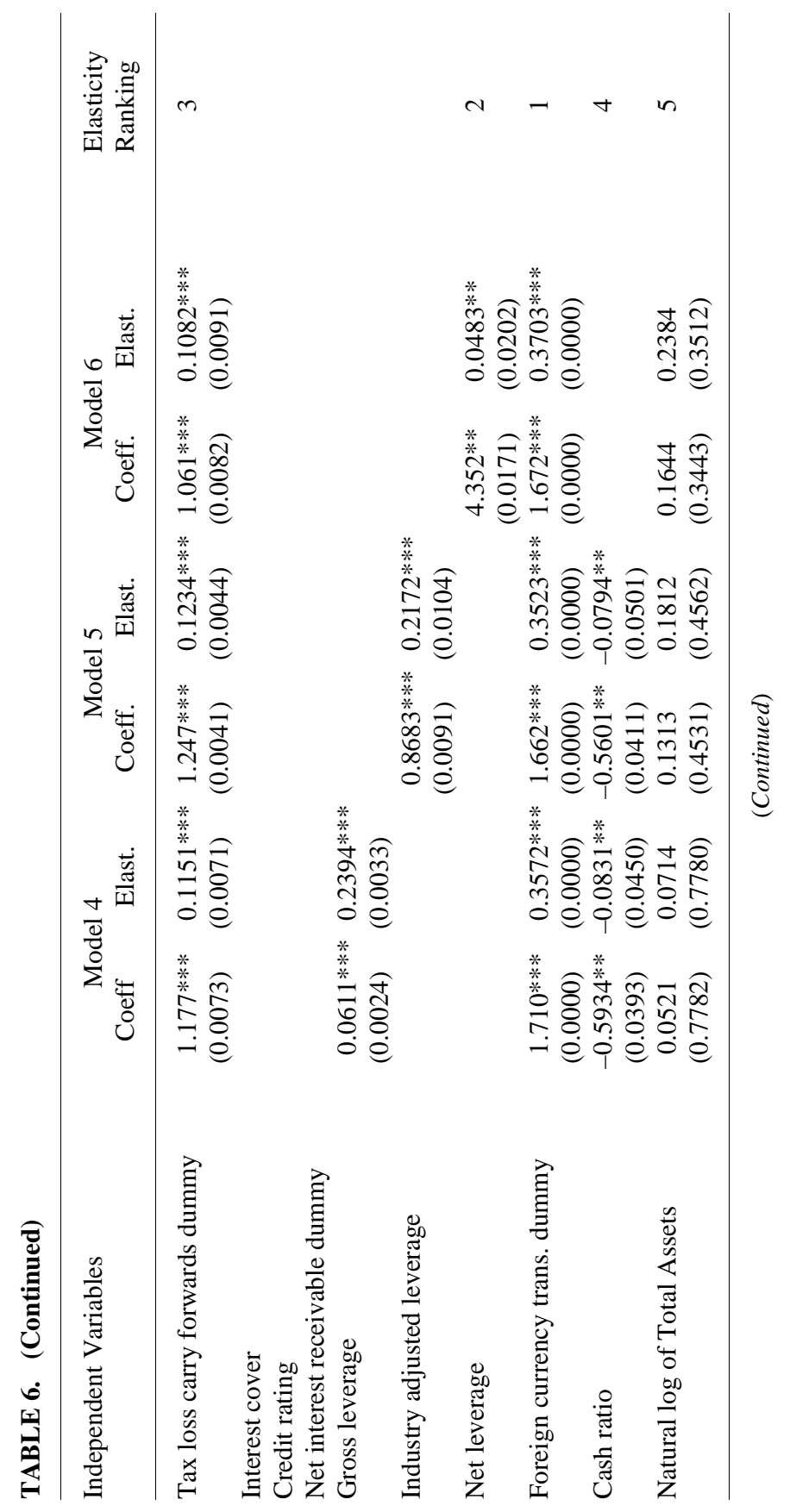




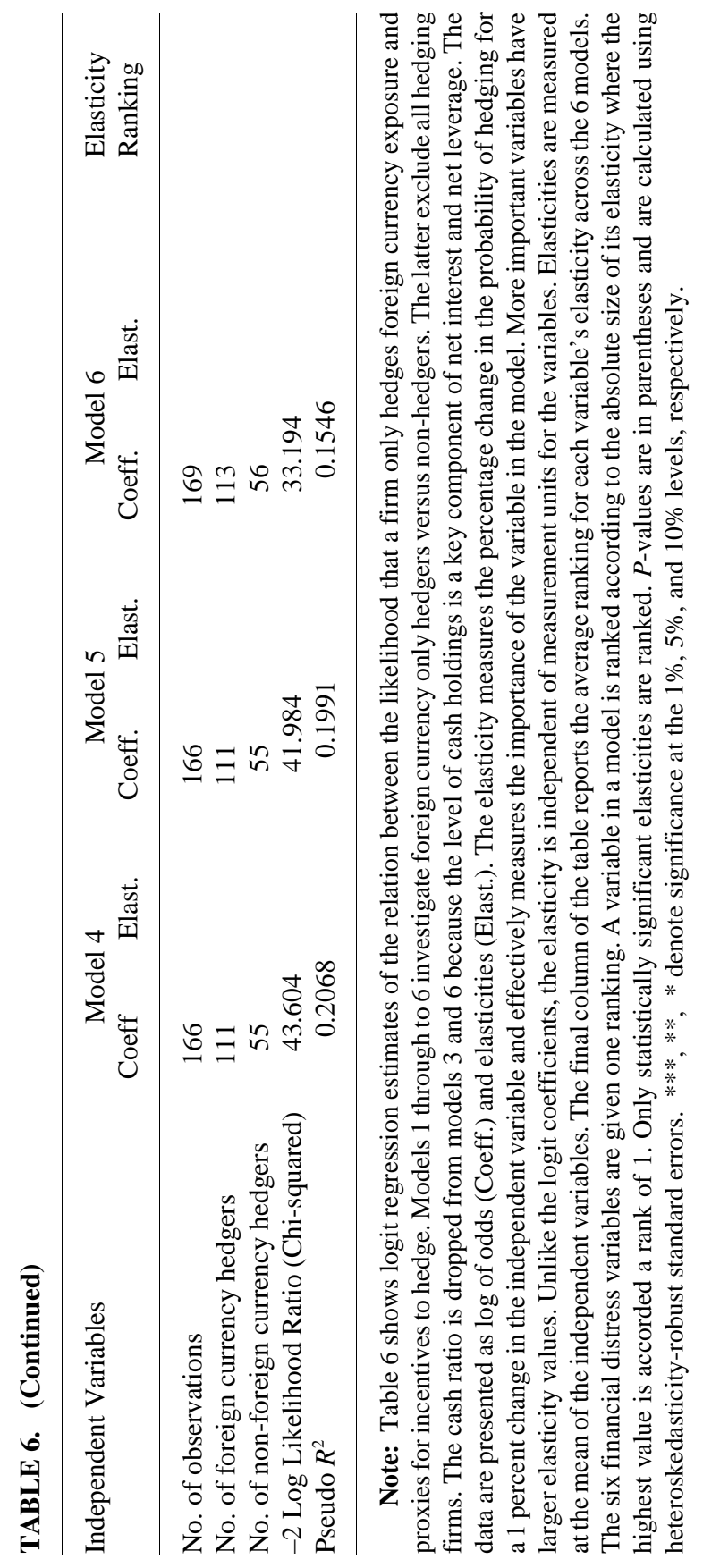




\section{Robustness Tests}

To facilitate comparisons with studies that investigate foreign currency derivatives use, I estimate a logit regression in which foreign currency derivative users are assigned a value of 1 and non-users a value of 0 for the binary dependent variable. This generates 215 foreign currency derivative users and 151 non-users. Non-users include 75 firms that hedge foreign currency exposure but do not mention the use of derivatives and 11 firms that only hedge interest rate exposure. Unreported results show that tax loss carry forwards, import/export activity and firm size are important factors in determining the use of foreign currency derivatives. Of the six proxies employed for financial distress costs only the estimated coefficient for the credit rating variable is significant and consistent with this hypothesis. Gross leverage and net leverage are both significantly negatively related to foreign currency derivatives use and the cash ratio is insignificant in all of the specifications estimated. ${ }^{18}$ I then remove from the sample the 75 firms that hedge foreign currency exposure but do not use derivatives. This leaves a sample composed of 215 foreign currency derivative users and 76 non-foreign currency hedgers. Unreported analysis shows a slight improvement in the relationship between the proxies for financial distress and the use of foreign currency derivatives. Two of these proxies are statistically significant (interest cover and credit rating). Furthermore, the cash ratio is significant in all specifications. Next, other hedging firms (mainly interest rate only hedgers) are excluded from the sample of non-foreign currency hedgers. This leads to a significant improvement for variables proxying for financial distress costs. Four financial distress proxies are significant and the signs are consistent with the predictions of the distress cost hypothesis (interest cover, credit rating, net interest receivable and leverage). These findings clearly demonstrate the effects of a bias resulting from the inclusion of interest rate hedging firms in the non foreign currency derivative user sample and potentially provide an explanation for the lack of evidence in support of the financial distress cost hypothesis in previous foreign currency hedging studies.

18. Géczy et al. (1997), Howton and Perfect (1998), Goldberg et al. (1998), Allayannis and Ofek (2001) and Hagelin (2003) also report a negative coefficient for the debt ratio. Graham and Rogers (2002) suggest that there could be a negative relationship between debt and foreign currency derivatives if foreign currency debt is a substitute for foreign currency derivatives hedging. 
A firm's decision about its capital structure can be made simultaneously with its decision to hedge (Mian [1996], Géczy et al. [1997] and Graham and Rogers [2002]). To control for the endogeneity of the capital structure and the foreign currency hedging decisions, I follow Géczy et al. (1997) and Graham and Rogers (2002) and estimate the determinants of these decisions simultaneously with a two-stage estimation technique. In the first stage, two separate regressions are performed using foreign currency hedging and the leverage ratio, respectively, as dependent variables. I exclude other hedgers from the non-hedger sample and use the specification in model 4 of table 4 to obtain predicted probabilities of foreign currency hedging. I specify the model of the capital structure decision following Rajan and Zingales (1995) to obtain predicted leverage ratios. In the second stage, structural equations are estimated using the predicted values from the first-stage regressions as explanatory variables.

In the second stage leverage regression unreported results show that the predicted probability of foreign currency hedging is significantly positively related to leverage. This indicates that hedging by U.K. firms increases their debt capacity. However, in the second stage hedging regression the predicted leverage ratio is not a statistically significant determinant of the foreign currency hedging decision. This result is consistent with the findings in section 4, which demonstrated that the leverage ratio is not a statistically significant determinant of the foreign currency hedging decision. Furthermore, unlike other financial distress proxies the significance of the three leverage ratios in section 4.2 is dependent on the exclusion of the small number of other hedgers in the non-hedging sample. This evidence supports the notion that leverage may not effectively capture the likelihood or the expected costs of financial distress. Consistent with this view Allayannis et al. (2003) use the interest coverage ratio and the Z-score as proxies for financial distress "because of the extensive prior evidence relating these variables to financial distress" (p. 2693) and Andrade and Kaplan (1998) find that financial distress costs are small even for highly levered firms.

Finally, it is conceivable that the inclusion of foreign debt users in the foreign currency hedging sample might drive the relationship between hedging and leverage and possibly other proxies for financial distress. ${ }^{19}$ Therefore, as an additional robustness check, I test for the endogeneity of the leverage ratio by excluding from the sample of

19. I thank an anonymous referee for pointing this out. 
foreign currency only hedgers firms that use foreign debt. This leaves a sample of firms that only hedge foreign currency exposure and only use foreign currency derivatives for hedging. Unreported results show that, although leverage is no longer a significant factor, the other financial distress proxies are statistically significant and consistent with the financial distress cost hypothesis. Therefore, the key result in this paper, namely that expected financial distress costs are an important factor in determining the foreign currency hedging decision, is robust to the exclusion of firms that use foreign currency debt.

\section{Conclusions}

The empirical tests in this paper examine the determinants of foreign currency hedging for a sample of U.K. non-financial firms. Unlike similar earlier studies, the empirical tests in this paper provide strong evidence of a link between foreign currency hedging and various proxies for the expected costs of financial distress. A firm's liquidity is also a significant determinant of foreign currency hedging which is consistent with the Nance et al. (1993) proposition that hedging and other financial policies, such as liquidity, are substitutes. The empirical analysis demonstrates that a firm's currency exposure is a very important factor that prompts firms to hedge. The evidence also shows that the size of the firm is positively related to the foreign currency hedging decision, indicating that larger firms are more likely to hedge than smaller firms. This result is consistent with significant information and transaction cost scale economies of hedging discouraging smaller companies from hedging.

The empirical analysis in this paper recognizes the existence of a potential bias created by including in the foreign currency hedging sample firms that hedge both foreign currency and interest rate exposure. This biases the results in favor of finding a significant relationship between foreign currency hedging and factors that might be more important to interest rate hedgers, such as leverage. The tests in this paper eliminate this bias by selecting foreign currency hedging firms that only hedge foreign currency exposure. The results show that several proxies for expected financial distress costs are important determinants of the likelihood of foreign currency hedging for this subsample of foreign currency hedgers. Therefore this study finds, to my knowledge for the first time, an unambiguous relationship between 
the decision to hedge foreign currency exposure and the expected costs of financial distress.

Overall, the results presented in this paper seem to be more supportive of a financial distress motive to hedge than those found in earlier, mainly U.S., empirical studies. One potential explanation is the suggestion that the tests in several U.S. studies are possibly biased against finding a significant relationship between foreign currency hedging and the expected costs of financial distress because in these foreign currency hedging studies the non-hedging sample includes "other" hedging firms. These firms could be those that hedge interest rate and/or commodity price exposure but not foreign currency exposure or firms that hedge foreign currency exposure with non-derivative methods such as foreign debt. These "other" hedgers might be hedging because of financial distress reasons (especially the interest rate hedgers) which potentially blurs the distinction between the two groups making it far more difficult to detect a relationship between foreign currency hedging and expected financial distress costs. Allayannis and Weston (2001) also recognize the existence of this bias in their study of the impact foreign currency derivatives use has on the value of U.S. firms. They find that their results are unchanged when they classify interest rate only hedgers and firms that use foreign debt but not foreign currency derivatives as hedgers. This result might imply that the bias in other studies, which employ samples that are not too dissimilar to that of Allayannis and Weston, is also small.

An alternative explanation for this apparent difference in the importance of financial distress as a motive for hedging between U.S. and U.K. firms is the possibility that expected financial distress costs are higher in the U.K. than they are in the U.S. This might be because of differences in the bankruptcy code between these countries (Judge [2006]). The bankruptcy code in the U.S. is regarded as shareholder friendly because it places greater emphasis on the shareholder retaining control in the event of default. On the other hand, the code in the U.K. is perceived as debt holder friendly because it confers greater rights to creditors when reorganizing a bankrupt company's affairs. If the U.K. rules make liquidation more likely for firms in financial distress, then U.K. firms potentially face higher expected costs of financial distress than firms in the U.S. This would suggest U.K. firms have a greater incentive to hedge in order to lower the expected value of these costs. Furthermore, theoretical research (Ross [1997] and Leland [1998]) argues that the reduction in expected distress costs as a result of hedging 
is less important than the interest tax shield from increased debt due to hedging for U.S. firms. Recent empirical research finds evidence in support of this (Graham and Rogers [2002]). Consistent with this view bankruptcy law differences might also partially explain the variation in other financial policy decisions between U.K. and U.S. firms. For example, Rajan and Zingales (1995) find that U.K. firms are less levered than firms in the U.S. They suggest that differences in bankruptcy codes seem to have some power in explaining differences in aggregate capital structure.

\section{APPENDIX 1. Variable Definitions and Summary of Hypotheses}

\begin{tabular}{|c|c|c|c|c|c|c|}
\hline & & & Hypoth & & & \\
\hline $\begin{array}{l}\text { Independent } \\
\text { Variable }\end{array}$ & $\begin{array}{l}\text { Tax } \\
\text { Sch } \\
\text { Conv. }\end{array}$ & $\begin{array}{l}\text { Financial } \\
\text { Distress }\end{array}$ & $\begin{array}{l}\text { Under- } \\
\text { invest/ } \\
\text { Costs of } \\
\text { Ext. Fin. }\end{array}$ & $\begin{array}{l}\text { Financial } \\
\text { Price } \\
\text { Exposure }\end{array}$ & $\begin{array}{l}\text { Substitutes } \\
\text { for Risk } \\
\text { Management }\end{array}$ & $\begin{array}{l}\text { Transaction } \\
\text { Cost } \\
\text { Economies } \\
\text { of Scale }\end{array}$ \\
\hline $\begin{array}{l}\text { Tax loss carry } \\
\text { forwards }\end{array}$ & + & + & & & & \\
\hline $\begin{array}{l}\text { Interest cover } \\
\text { ratio }\end{array}$ & & - & & - & & \\
\hline $\begin{array}{l}\text { Credit rating } \\
\text { (Qui-score) }\end{array}$ & & - & & & & \\
\hline $\begin{array}{l}\text { Net interest } \\
\text { charge }\end{array}$ & & - & & - & & \\
\hline Gross leverage & & + & + & + & & \\
\hline $\begin{array}{l}\text { Industry adjustec } \\
\text { gross leverage }\end{array}$ & & + & + & + & & \\
\hline Net leverage & & + & + & + & & \\
\hline $\begin{array}{l}\text { Capital } \\
\text { expenditure }\end{array}$ & & & + & & & \\
\hline $\begin{array}{l}\text { Market-to-book } \\
\text { value ratio }\end{array}$ & & & + & & & \\
\hline $\begin{array}{l}\text { Research and } \\
\text { development } \\
\text { expenditure }\end{array}$ & & & + & & & \\
\hline $\begin{array}{l}\text { Foreign sales } \\
\text { by destination }\end{array}$ & & & & + & & \\
\hline
\end{tabular}




\author{
Foreign \\ transactions \\ dummy
}

Cash ratio

Convertible

debt

Firm size

\begin{tabular}{lll} 
& + & \\
+ & - & - \\
- & - & + \\
\hline
\end{tabular}

This appendix presents the independent variables for the analysis of hedging by U.K. non-financial firms. It provides the variable's definition, the source of data for the variable, and the predicted sign of the coefficient estimate as predicted by each hypothesis. All variables are computed as three-year averages up to one year prior to the 1995 year-end, unless stated otherwise. Definitions for Variables: Tax loss carry forwards: A dummy variable equal to 1 if the firm has tax loss carry forwards for the year ended 1995. (Annual report): Interest cover ratio: Profit before interest and tax divided by interest payments. (Datastream): Credit rating (Qui-score): Qui-score is a measure of the likelihood of firm failure in the twelve months following the date of calculation. The Qui-score is given as a number in the range 0 (high likelihood of failure) to 100 (low likelihood of failure). This variable is collected for the year ended 1994. (FAME); Net interest charge: A dummy variable equal to 1 if a firm is a net receiver of interest in any given year, where net interest is defined as total interest charges less interest income. The dummy value is averaged over 3 years prior to the annual report year end. (Datastream); Gross leverage: Book value of total debt and preference capital as a proportion of the book value of total debt plus the market value of equity. (Datastream); Industry adjusted gross leverage: The gross leverage for a firm divided by average gross leverage for the industry. Industry classifications sourced from Datastream; Net leverage: Book value of net debt and preference capital as a proportion of the book value of net debt plus the market value of equity, where net debt is total debt less cash and short-term investments. (Datastream); Capital expenditure: Purchases of fixed assets divided by total sales. (Datastream); Market-to-book value ratio: The market value of equity divided by book value of equity, where the book value of equity is measured as equity capital and reserves (excluding preference capital) less goodwill and other intangibles. (Datastream); Research and development expenditure: Research and development expenditure divided by total sales. (R\&D Scoreboard compiled by Company Reporting Ltd.); Foreign sales by destination: Foreign sales by destination divided by total sales for the year ended 1994. (Annual report); Foreign transactions dummy: A dummy variable equal to 1 if a firm indicates that it imports or exports or repatriates dividends and other investment income back to the UK for the year ended 1995. (Annual report); Cash ratio: Total cash and cash equivalents divided by total current liabilities. (Datastream); Convertible debt: Book value of convertible debt divided by total assets. (Datastream); Firm size: Natural logarithm of the book value of total assets. (Datastream)

\section{References}

Allayannis, G., and Ofek, E. 2001. Exchange-rate exposure, hedging and the use of foreign currency derivatives. Journal of International Money and Finance 20:273-296.

Allayannis, G., and Weston, J.P. 2001. The use of foreign currency derivatives and firm market value. Review of Financial Studies 14:243-276. 
Allayannis, G.; Brown, G.W.; and Klapper, L.F. 2003. Capital structure and financial risk: Evidence from Foreign Debt Use in East Asia. Journal of Finance 58:2667-2709.

Andrade, G., and Kaplan, S.N. 1998. How costly is financial (not economic) distress? Evidence from highly leveraged transactions that became distressed. Journal of Finance 53: 1443-1493.

Berkman, H., and Bradbury, M.E. 1996. Empirical evidence on the corporate use of derivatives. Financial Management 25:5-13.

Bessembinder, H. 1991. Forward Contracts and Firm Value: Investment Incentive and Contracting Effects. Journal of Financial and Quantitative Analysis 26:519-532.

Brown, G. 2001. Managing foreign exchange risk with derivatives. Journal of Financial Economics 60:401-448.

Dolde, W. 1995. Hedging, leverage, and primitive risk. The Journal of Financial Engineering, 4:187-216.

Elliott, W.B.; Huffman, S.P.; and Makar, S.D. 2003. Foreign denominated debt and foreign currency derivatives: Complements or substitutes in hedging foreign currency risk. Journal of Multinational Financial Management 13:123-139.

Fok, R.C.W.; Carroll, C.; and Chiou M.C. 1997. Determinants of corporate hedging and derivatives: A revisit. Journal of Economics and Business 49:569-585.

Francis, J. and Stephan, J. 1993. Characteristics of Hedging Firms: An Empirical Investigation. In R.J. Schwartz and C.W. Smith, Jr., (eds). Advanced Strategies in Financial Risk Management. New York Institute of Finance.

Froot, K.A.; Scharfstein, D.S.; and Stein, J.C. 1993. Risk management: Coordinating corporate investment and financing policies. Journal of Finance 48:1629-1658.

Gay, G.D., and Nam, J. 1998. The Under investment Problem and Corporate Derivatives Use. Financial Management 27:53-69.

Géczy, C.; Minton, B.A.; and Schrand, C. 1997. Why firms use currency derivatives. Journal of Finance 52:1323-1354.

Goldberg, S.R.; Godwin, J.H.; Kim, M.; and Tritschler, C.A. 1998. On the determinants of corporate usage of financial derivatives. Journal of International Financial Management and Accounting 9:132-166.

Graham, J.R., and Rogers, D.A. 2000. Is corporate hedging consistent with value-maximization? An empirical analysis. Working paper. Fuqua School of Business, Duke University.

Graham, J.R., and Rogers, D.A. 2002. Do firms hedge in response to tax incentives? Journal of Finance 57:815-839.

Graham, J.R., and Smith, C.W. 1999. Tax incentives to hedge. Journal of Finance 54:2241-2262.

Guay, W., and Kothari, S.P. 2003. How much do firms hedge with derivatives? 
Journal of Financial Economics 70:423-461.

Hagelin, N. 2003. Why firms hedge with currency derivatives: An examination of transaction and translation exposure. Applied Financial Economics 13:55-69.

Howton, S.D., and Perfect, S.B. 1998. Currency and interest-rate derivatives use in U.S. firms. Financial Management 27:111-121.

Judge, A.P. 2006. Why and how UK firms hedge. European Financial Management. 12:404-441.

Kedia, S., and Mozumdar, A. 2003. Foreign currency denominated debt: An empirical investigation, Journal of Business 76:521-546.

Keloharju, M., and Niskanen, M. 2001. Why do firms raise foreign currency denominated debt? Evidence from Finland. European Financial Management 7:481-496.

Leland, H.E. 1998. Agency costs, risk management, and capital structure. Journal of Finance 53:1213-1243.

Mayers, D., and Smith, C.W. 1982. On the corporate demand for insurance. Journal of Business. 55:281-296.

Mayers, D., and Smith, C.W. 1987. Corporate insurance and the Under investment decision. Journal of Risk and Insurance 54:45-54.

Mian, S.L. 1996. Evidence on corporate hedging policy. Journal of Financial and Quantitative Analysis 31:419-439.

Modigliani, F., and Miller, M.H. 1958. The cost of capital, cor $\neg$ porate finance and the theory of investment. American Economic Review 48:261-197.

Myers, S.C. 1977. Determinants of corporate borrowing. Journal of Financial Economics 5: 147-175.

Nance, D.R.; Smith, C.W.; and Smithson, C.W. 1993. On the determinants of corporate hedging. Journal of Finance 48:267-284.

Phillips, A.L. 1995. 1995 Derivatives practices and instruments survey. Financial Management 24:115-125.

Rajan, R., and Zingales, L. 1995. What do we know about capital structure? Some evidence from international data. Journal of Finance 50:1421-1460.

Ross, M.P. 1996. Corporate hedging: What, why and how. Working paper Berkeley: University of California.

Smith, C.W., and Stulz, R.M. 1985. The determinants of firms' hedging policies. Journal of Financial and Quantitative Analysis 20:391-405.

Tufano, P. 1996. Who manages risk? An empirical examination of risk management practices in the gold mining industry. Journal of Finance 51:1097-1137.

Wysocki, P. 1995. Determinants of foreign exchange derivatives use by U.S. corporations: An empirical investigation. Working paper. Simon School of Business: University of Rochester.

Wysocki, P. 1996. Managerial motives and corporate use of derivatives: Some evidence. Working paper. Simon School of Business: University of Rochester. 